\title{
АКТУЕЛНОСТ БЕЛИЋЕВОГ ПОГЛЕДА НА ГЛАГОЛСКЕ ДОПУНЕ
}

\begin{abstract}
У првом делу овог истраживања дат је осврт на значајније резултате Белићевих лингвистичких истраживања, на основу његових радова и студија, као и на основу неколико релевантних критичких приказа његових основних теоријских поставки везаних првенствено за синтагму које су написали савременици и следбеници Белићевих идеја. У другом делу рада говори се о томе какви су домети његовог учења о синтагми били пре свега у српској лингвистици 20. века. Затим су предочени резултати новијих истраживања у српској синтакси у чијем су фокусу биле допуне глагола да би се показало како је Белићев концепт синтагме уграђен у другачије теоријско-методолошке оквире.
\end{abstract}

Кључне речи: Александар Белић, стандардни српски језик, глаголска допунска синтагма, допуне и додаци.

1. Увод: кратак осврт на значај Белићеве лингвистике. Прва и друга књига академика А. Белића O језичкој природи и језичком развитку са поднасловом Лингвистичка испитиваюа, ${ }^{1}$ несумњиво најзначајнија општелингвистичка студија код Срба у 20. веку, прештампана је као први том Изабраних дела А. Белића под насловом Општа лингвистика (1998). Приређивач овог издања академик Милка Ивић² у самом предговору истиче како та књига заправо представља аутора: „У најкраћем овако: по избору визура из којих разгледа језик - несличан иностраним великанима лингвистике тога времена, а по свом 'лингвистичком проповедању' - антиципатор неких од потоњих виђења ствари” (1998: 6). По њеним речима, Белић је антиципирао пре свега основне по-

1 Прво издање прве књиге штампано је 1941, друго 1958, док је друга књига објављена 1959.

2 М. Ивић је била Белићев студент и под његовим менторством урадила је докторску тезу о инструменталу и објавила ју је 1954. као монографију у издању Српске академије наука под насловом: Значена српскохрватског инструментала и ғихов развој (синтаксичко-семантичка студија). 
ставке Филморове теорије о дубинским падежима јер је падеже сагледавао као семантичке јединицез. Такво запажање да је Белић претеча генеративне семантике, правца у лингвистици који је настао касније, изнео је и знаменити хрватски лингвиста Радослав Катичић у свом приказу Белићевог учења о синтагми. По његовим речима, „Белић је у своју синтагматику увео не само дубинску семантичку структуру" него и имплицитно примењивао „метод трансформације”, како би објаснио „пријелаз од универзалног семантичког устројства реченице до њеног граматичког обликовања" (Катичић 1976: 179).

М. Ивић у поменутом предговору приређене књиге (1998, 6-8) помиње и друге научне доприносе свог професора потоњој лингвистици, као што је рецимо разлагање лексичких јединица на „конститутивне елементе" или пак његову поделу именица на праве и неправе, што је у основи теорије о прототипима. ${ }^{4}$

1.1. О дометима Белићевог учења било је много дискусија међу лингвистима средином 20. века, а у словенском свету највише пажње је изазвало његово тумачење синтагме као групе речи које су ,органски' повезане у јединствену целину, и као такве оне се појављују, поред речи и реченице, у готово свим језицима света. ${ }^{5}$ Та унутрашња форма, то јединство представе, тај интерни однос или тзв. лингвистичка релација, постојала је у језику и пре него што је створен посебан језички облик, који може бити мењан или изгубљен током језичког развоја, али оно што остаје, то је та релација: „Она је од фундаменталног значаја за језик, што није форма, која може бити само привременог карактера", наглашава Белић у свом „Писму о лингвистици” (1998: 11). ${ }^{6}$

${ }^{3}$ На то је скренула пажњу М. Ивић још 1968. у Токију на Трећем међународном семинару о лингвистичкој теорији (1998: 6). Темеље генеративној семантици поставио је Ch. J. Fillmore у студији: The case for case (Universals in linguistic theory - E. Bach, R. T. Harms, eds. N.Y. 1968).

${ }^{4}$ М. Ивић посебно осветљава допринос Белићевог учења о именицама у својој студији која је објављена 1976. у Зборнику радова о Александру Белићу.

${ }^{5}$ Било је лингвиста, истина незнатан број, који су истицали терминолошко-лингвистичку непрецизност у Белићевим излагањима или недовољно јасно дефинисање језичких појмова и појава. На изузетно позитивне одјеке његове лингвистике у ширим европским оквирима указала је М. Ивић у поменутом предговору (1998: 1-12).

${ }^{6}$ То је објављено на енглеском језику, према наводима М. Ивић, у књизи For Roman Jakobson (The Hague 1956, 31-33). 
1.2. Теоријско-методолошке оквире своје лингвистике сам Белић јасније је образложио у студији „О лингвистици проф. А. Белића” (1949/50, 1-37), која је иницирана од његових ученика. Одатле наводим само његове констатације које се односе на значај синтагме за проучавање падежних односа, али су везане и за језички развој уопште: „Без синтагме нема зависних облика падежа .... или „најпростије посматрање облика у синтагмама даје нам јасну претставу о природи облика" (1949/50, 25). А мало даље Белић каже: „у односима речи у синтагми и реченици видим извесне врсте законитости која је условљена самом природом речи, природом њених претстава, управо природом њихова значења” ... „Како су синтагме носиоци унутрашњих односа међу речима, то се облици мењају и у зависности од промене самих гласова у њима и од најразличитијих односа обличких система” ...У границама истих обличких синтагма могу се развијати нова значења" (Белић 1949/50: 25). Да је значењски аспект релевантан за проучавање језичких јединица удружених у синтагме, јасно је показао Белић говорећи о развоју блиских значења различитих падежа.

1.3. Наш граматичар М. Стевановић (1988), као несумњиво највернији следбеник Белићевог учења о синтагми (постулате те теорије пренео је у своју граматику Савремени српскохрватски језик), истиче следеће битне ствари: да је А. Белић највише заслужан за дефинисање синтагме и сагледавање њеног значаја у проучавању језичких појава, као и за то да се схватање синтагме не ограничава само на област падежа већ и на сложене и изведене речи, па и на поједине категорије речи (нпр. личне заменице). Сем тога, треба знати да се синтагматски односи уочавају не само у флексивним језицима него и у онима где нема падежа и у којима нема ни развијених реченица (Стевановић 1988: 73-74).

1.4. За представнике генеративне граматике, посебно семантике, биле су примарне семантичке улоге падежа, док су од секундарног значаја њихови синтаксички изрази. ${ }^{7}$ Исти приступ у проучавању падежних односа има А. Белић, који запажа, између осталог, да и када се падежни облици сведу на само четири форме, као у грчком или немачком језику, ипак се чувају различита падежна значења, а то исто потврђују и примери синкретизма множинских падежа у нашем језику: људима говори, са људима говори и о тудима говори (Белић 1953/4: 23).

${ }^{7}$ На семантичке категорије које претходе конкретним лексичким реализацијама у реченици указали су генеративни семантичари нпр. G. Lakoff (Toward Generative semantics, 1978). Белић је, међутим, истакао да је још Панини, знаменити индијски граматичар, полазио од значења падежа а не од облика и по том значењском критерију систематизовао је падеже (Белић 1958: 137). 
1.5. Сумирајући овај кратак преглед Белићевог доприноса развоју српске лингвистике у прошлом веку, требало би посебно упутити на речи хрватског лингвисте Р. Катичића, забележене у Зборнику радова о А. Белићу: „А. Белић у Срба је развио лингвистику до завидне висине ... и за читав је учени свијет био висок ауторитет у свим питањима српскога и хрватскога језика”, а уз то и на следеће: „Колико год се, дакле, сјећали њега као учитеља српскога или хрватскога језикословља, увијек ћемо о њему морати судити и као о великом мислиоцу лингвистичке теорије" (1976: 173). За ову прилику вредна је подсећања и Катичићева тврдња „Нема двојбе да је баш у синтагматици Белић као опћи лингвист и као теоретичар језика најзнатнији и највише свој” (1976: 175).

И сасвим у складу са свим изреченим, а и оним овде непоменутим оценама Белићевог научног доприноса развоју лингвистичке мисли код нас и у свету, први том приређених Изабраних дела А. Белића носи наслов Општа лингвистика. Своју тврдњу да је ,лингвистика лингвистичка, он објашњава укратко овако: „све појаве се морају проучавати с погледом на то како се оне манифестују у језику и са каквом тенденцијом даљег развоја" (1998: 11). Несумњива самосвојност Белићевог приступа језику, по речима Р. Бошковића, огледа се управо у његовом оригиналном погледу на развитак и природу самог језика (1998: 6).

2. О Белићевом поимању зависне синтагме. Белић синтагму дефинише као групу од две или више речи везаних унутрашњим јединством представе или функције. ${ }^{8}$ Шта значи органско јединство или повезаност две речи у једну целину, он то показује најбоље на примерима различито структурираних зависних синтагми: придев + именица, прилог + глагол, глагол + именица у акузативу или у инструменталу (Белић 1953/54: 11). За њега су зависне синтагме двојаке: у једнима се зависним чланом открива особина што се као језички потенцијал садржи у главноме члану (атрибутске и прилошке), а у другима је зависни члан саставни део појма изван њега, али с њим чини органску целину као објекат са својим глаголом или оруђе којим се врши радња, опет у јединству с том радњом (орати плугом). Једне зове одредбеним (детерминативним) а друге допунским, али, будући да су све детерминативног карактера, касније употребљава други термин за ове прве и зове их описним (придевског, при-

8 Значајно је то што је Белић синтагму која је дата у говору као готова језичка јединица са својим семантичким потенцијалом, супротставио реченици која се у моменту говора ствара. По његовим речима, једна је статика, а друга динамика (Белић 1958: 99). 
лошког типа) како би их одвојио од допунских (падежних) из којих се развијају оне прве (Белић 1953/4: 4-5).

2.1. Наслањајући се на резултате истраживања својих претходника, како руских тако и других европских синтагматичара, наш истакнути лингвиста Радоје Симић (1999) уводи нешто другачији приступ и нову терминологију у објашњавању тзв. описних вишечланих конструкција. Оне могу бити, као прво, организоване на принципу међуусловљености језичких јединица, па ту разликује обавезне, које настају допуњавањем (када управна реч својим лексичко-граматичким својствима одређује функцију зависне речи, чији је, према његовим речима, екстремни вид морфолошког обележавања - рекиија $)^{9}$, и необавезне које настају додавањем или адлокацијом (тј. дозвољеном синтагматском комбинацијом више јединица, према граматичким и лексичким правилима језика). У првима имамо падеже унутрашње детерминације, а у другима као посебном виду истог зависног односа - падеже спољашње детерминације (Симић 1999: 183).

3. Глаголске допуне синтагме и допуна. ${ }^{10}$ Појам допуне у српску синтаксу увео је А. Белић у оквиру свог учења о синтагми. Он њу углавном поистовећује с објектом, који не мора бити, по његовим речима, исказан, откривен, објављен, већ изостављен, прећутан, латентан, јер: „У језику се ретко кад открива све оно што је условљено природом самих речи, већ само онолико колико смисао реченице захтева" (1953/54: 18). Исто тако Белић утврђује да је „друга ствар кад се глагол употреби не да се покаже реализација радње, већ да се изнесе особина каква (он пише, у значењу он је nuсаu) или кад глагол без објекта има сасвим друго значење" (нпр. ако „,је ли свршио” значи , је ли умро”). Познато је да употреба именичке лексеме у функцији објекта може да утиче на мењање значења управне глаголске речи, али и одсуство објекта може да доведе до мењања његовог категоријалног обележја и стварања новог значења. ${ }^{11}$

Допунске синтагме (типа купио је краву, дао је новаи пријатељима, орали су плугом) Белић (1953/54: 10) објашњава овако:,, за све прелазне глаголе важи да садрже у себи латентне објекте ... они су органски делови

9 Р. Симић рекцију дефинише као својство фокализиране (управне) речи да семантички инкорпорира другу реч и управља при томе њеним обликом (1999: 180). Она је карактеристична и за именице, придеве и прилоге као управне речи. Он прави и разлику између непосредне и посредоване рекције (када су неправи објекти везани за неправе прелазне глаголе).

10 Падежној допунској синтагми А. Белић посвећује доста простора (1958: 96-106).

11 О томе како долази до преплитања прелазне и непрелазне аперцепције глаголског значења врло детаљно пише И. Грицкат у својој студији, сагледавши ту појаву и са дијахроног аспекта и контрастивно (1975: 229-263). 
глагола чинећи са њим целину... рецимо „код глагола дати има два таква момента ... када се даје мора се некоме дати и мора се нешто дати ... Када се за то употребе именице (у дативу и акузативу ...) ...глагол се допуњује оним што он у себи садржи као латентне, саставне делове." Уз глагол ора$m u$ рецимо именицом (у инструменталу) открива се латентни инструмент 'сакривен' у самом глаголу, али то оруђе може бити означено самом именицом (која није у инструменталу, нпр. Нокти су му, орати би мо2ao), што се лепо показује у нефлексивним језицима (1953/54: 14). Управо његове констатације да су ти „унутрашњи моменти глаголске радње, без којих она није потпуна, оне допуне које и чине потпуност реализованог глаголског појма или органску глаголску целину" (1953/54: 15) а да могу, али не морају бити изречени, можемо повезати са основним поставкама граматике зависности да глагол као структурно средиште реченице, својим потенцијалом отвара место неопходним, обавезним номиналним и другим допунама. ${ }^{12}$

3.1. У руској синтакси постоји термин управљање којим се именује посебна врста синтагматског односа који не зависи од синтаксичке реализације глагола у реченици; тај однос се успоставља између глагола и његове падежне, објектне допуне (за које важе падежна питања), чије се форме не мењају, а прелазни глагол заједно са беспредлошким и предлошким допунама гради моделе и подмоделе управљања како је то показао руски лингвиста на примерима енглеских и руских глагола (Мухин 1987: 98-243). ${ }^{13}$ Често се прави разлика и између јаке и слабе рекције, које се остварују у везама глагола, правих или неправих прелазних, као управних речи и њихових именских допуна у функцији објеката. ${ }^{14}$

12 Код представника депенденцијалне немачке граматике, као што је Енгел (од кога је П. Мразовић преузела одређења и типологију допуна, применивши то на српској језичкој грађи), допуне су супкласно специфичне и предодређене, док додаци нису. Модел депенденцијалне граматике представљен је у Граматици српскохрватског језика за странце (Мразовић/Вукадиновић 1990).

13 То како се при одређивању прелазности глагола примењују методе трансформације (пасивизације), супституције облика допуне, па падежно питање за објектне допуне, као и метод елиминације (односно критериј обавезности, необавезности) детаљно објашњава Мухин (1987: 88-92).

14 Глаголску рекцију дефинише Гортан-Премк (1977: 237): „као компоненту опште глаголске вредности која условљава могуће директне, непосредне семантичко-синтаксичке односе зависних именичких речи према глаголу као главној, управној речи у синтагми.” 
3.2. У свом прилогу класификацији глаголских допунских конструкција (Петровић 1992), извршила сам типологију допуна глагола полазећи од лексичкосемантичке целовитости две речи у датом споју (нпр. настаје мрак), структурнофункционалне нерашчлањивости дате везе и формално-категоријалног обележја зависног дела, те сам одвојила лексичке ${ }^{15}$ од граматичких, падежних, рекцијских допуна, чија је појава условљена значењем управних речи, а које врше одређену синтаксичку функцију у реченици. ${ }^{16}$

3.3. Позивајући се на оно што је већ утврђено у депенденцијалној граматици о статусу и односу допуна и додатака, М. Алановић је предложио другачију хијерархију критерија за њихово разграничење и уједно направио дистинкцију између семантичке обавезности /односно факултативности и прагматички условљене испустивости допуна. При томе он је у посебну прелазну групу с разлогом издвојио тзв. адјункте (прилошке, адвербијалне допуне) као обавезне, проширујуће додатке. ${ }^{17}$ Допуне су супкласноспецифичне (валентно специфичне за одређене класе глагола), формално предодређене и обавезне (премда су испустиве), док су додаци увек факултативни и испустиви. ${ }^{18}$ Објекат је увек маркирани реченични члан (било наставачком морфемом, било предлогом или по-

${ }^{15}$ Према ауторима хрватске граматике, постоје везани спојеви речи са сузначним речима - са копулативним, неправим копулативним, фазним, модалним, перифразним глаголима и квантификаторима и њиховим лексичким допунама (Силић/Прањковић 2005: 269-270). У те лексичке допуне које чине семантичко-функционално јединство са семантички недовољно оформљеним речима спадају тзв. предикативне или предикатске допуне, као именски делови предиката, а у Граматищи српскога језика то су именски (216) и допунски предикативи (228). Они чине тзв. лексичка језгра предиката будући да су у његовом саставу.

16 У допуне сам уврстила и адвербијалне (прилошке) и агентивне, не водећи рачуна о њиховој аспецифичности, премда сам указала на битне разлике међу њима.

17 Г. А. Золотова (1973: 62) говори такође о томе да значењски потенцијал и друга категоријална обележја управног глагола имају битну улогу при успостављању различитих веза између њега као управне речи и зависне речи, што именује терминима: управление и сложение. За прве је карактеристично да се зависне именске речи појављују у одређеној везаној форми, а друге (прилошке) се остварују у слободним формама.

18 Субјекат, који се сматра глаголском допуном у теорији валентности, категоријално је неспецифична допуна и испустив је у појединим језицима, јер су његов облик и статус у домену категоријалне рекције (Алановић 2012: 154-155). 
ствербалном позицијом), али када је део базичне валентности глагола онда је обавезан, а када то није онда је факултативан. ${ }^{19}$

3.4. У погледу утврђивања обавезности допуна и додатака руски синтаксичари су говорили о различитим аспектима тога критерија: комуникативном, семантичком и синтаксичком. Допуне су увек семантички обавезни делови потенцијала глагола, али на синтаксичком и комуникативном плану, оне могу бити испустиве, а да се при том не мења категоријално обележје прелазности самог глагола: Она чита; Они једу а ми гледамо. Да ли имаш кућу? Имам. У оваквим случајевима, према тумачењу И. Грицкат, ради се о тзв. ситуационој интранзитивности, не и граматичкој (1975: 240).

Исто то потврђује Н. Арсенијевић у свом раду о транзитивно-интранзитивној концепцији глагола у српском језику: „испуштање објекатског конституента уз транзитиван глагол представља ситуациону интранзитивност - факултативну синтаксичку појаву, док транзитивна семантика датог глагола остаје непромењена" (2012: 168-170). Уз транзитиван глагол, каже Н. Арсенијевић, објекат је увек или експлициран или имплицитан, додајући да с друге стране, постоје глаголи чија је семантика заснована управо на транзитивно-интранзитивној концепцији, тако да се некима од значења обухвата обавезно и објекат, а истовремено је актуелно једно или више значења која га не укључују." У оваквим запажањима могу се препознати темељи Белићевог учења без обзира на то да ли се они тичу природе глаголских речи, падежних облика или његовог студиозног проучавања синтагматских односа.

3.5. У новије време у лингвистици су изражене тенденције да се појаве у језику објашњавају као резултати сложених когнитивних процеса, тако да се и о категорији објекта и о категорији прелазности може говорити са тог аспекта.

Нека своја запажања о томе како се у нашој спознаји света концептуализују представе о основним транзитивним радњама с инкорпорираним „објектима”, својственим човеку као свесном људском и друштвеном бићу, којима он несвесно или свесно овладава од најранијег детињства, изнела сам у једном раду (Ружић 2006). Ако су радња и њен потенцијално остварив објекат конципирани као нерашчлањени у људском искуству, као да су срасли у једну семантичку целину, нема потребе за ње-

19 У раду о предлошком објекту (Петровић 2000) за тај објекат кажем да је увек маркиран као нетипичан. 
говим издвајањем, а, према Белићевој терминологији, „објављивањем” ${ }^{20}$ Оно што је недовољно диференцирано у нашој спознаји и(ли) садржи својеврсни квалификатив, повезано је у чврсту семантичку везу и као такво је аперципирано, на шта је још Белић давно скренуо пажњу истичући 'јединство значења, представе' о каквом појму. Неке радње могу бити конципиране и као стања с експеријенсером, али и као радње с активним вршиоцем.

3.6. Александар Белић је језичке појаве сагледавао и из синхроне и из дијахроне перспективе, па је делове својих лингвистичких испитивања посветио и ,језичком развитку” уопште (1958) и „развитку синтагма и њихових значења" (1958: 137-143).

Из визуре историчара језика наша истакнута лингвисткиња Ј. Грковић-Мејџор објашњава како је текао развој категорије синтаксичке транзитивности и како је дошло до ширења акузатива директног објекта уз поједине групе глагола, и то на основу резултата својих истраживања спроведених на корпусу најстаријих словенских споменика. Она, између осталог, каже да типолошки преображај језика доводи и до стварања опозиције транзитив - интранзитив, а то значи и инваријантне форме субјекта којим се исказују различите семантичке улоге ... и инваријатне форме директног објекта, који опет, представља различите семантичке улоге" (2007: 419). Прву такву семантичку типологију објекта у српском језику извршила је Н. Арсенијевић у својој књизи Падежи правог објек$m a$, где је издвојила више семантичких класа глагола који везују за себе различите типове правог објекта (Арсенијевић 20126: 26-29).

4. Закључци. И на крају, да о језичкој природи и језичком развитку и значају синтагми за тај развој - опет проговоримо Белићевим језиком: „Организоване групе речи око субјекта и предиката дају и претставу о свима врстама речи и о свима променама којима се реч у језицима може подвргнути (Белић 1998: 473); ... цела језичка архитектоника и почива на развијању односа који потичу од онога што се по природи сваког језика и сваког мишљења крије у субјекатским и предикатским деловима реченичним. Отуда је и сасвим природно што има ... много језика у којима је природа свих односа у језику синтагматска" (1998: 131).

Наведена Белићева запажања, која су, чини се, пре свега резултат његове интуитивне спознаје језичких законитости и језичког развоја,

20 у поглављу књиге Проста реченииа (Пипер и др. 2006: 505) указала сам на то да податак о објекту изостаје онда када радње обухватају опште познате предмете, тј. објекте који постоје у људском искуству као универзалне семантичке категорије. 
могу послужити уместо закључака овога истраживања о значају Белићевог учења о синтагматици, његовог самосвојног лингвистичког промишљања језичких појава. Додајмо и то да је неспорно Белићев концепт зависне синтагме уграђен у сва потоња, овде поменута учења о синтагматским спојевима речи, односно о рекцијским односима унутар глаголских конструкција, али је посебно значајан његов допринос у проучавању падежне проблематике, о чему овом приликом нисмо могли говорити.

\section{ЛИТЕРАТУРА}

Алановић 2012: М. Алановић, Допуне и додаци - између обавезности и испустивости, Годишғак ФФ у Новом Саду, XXXII, 145-162.

Арсенијевић 2010: Н. Арсенијевић, Семантика правог објекта у стандардном српском језику, Српски језик, серија I, год. XV/1-2, 177-187.

Арсенијевић 2012: Н. Арсенијевић, Транзитивно-интранзитивна концепција неких глагола у српском језику, Међународни зборник радова: Валентност речи и израза, Нови Сад: Филозофски факултет, 163176.

Арсенијевић 2012б: Н. Арсенијевић, Падежи правог објекта у стандардном српском језику, Нови Сад: Филозофски факултет у Новом Саду.

Белић 1949-1950: А. Белић, О лингвистици А. Белића, Јужнословенски филолог, XVIII, 1-37.

Белић 1953-1954: А. Белић, О значају синтагма за развитак језичких појава, Јужнословенски филолог, ХХ, 1-27.

Белић ${ }^{2}$ 1958: А. Белић, О језичкој природи и језичком развитку. Лингвистичка испитиваюа, І књ., Београд: Нолит.

Белић 1998: А. Белић, Општа лингвистика. Изабрана дела А. Белића, том 1, Београд: Завод за уџбенике и наставна средства.

Гортан-Премк 1977: Д. Гортан-Премк, „О неким питањима двојаке глаголске рекције”, Јужнословенски филолог, XXXIII, 237-246.

Грицкат 1973: И. Грицкат, „Из проблематике прелазности српскохрватских глагола", Јужнословенски филолог, XXX/1-2, 297-303.

Грицкат 22007: И. Грицкат, Студије из историје српскохрватског језика, Београд: Завод за уџбенике и наставка средства.

Грковић 2007: J. Грковић-Мејџор, „Развој синтаксичке транзитивности”. Зборник за славистику, 71-72, 417-435. 
Золотова 1973: Г. А. Золотова, Очерк функционального синтаксиса русского, Москва: Наука.

Ивић 1976: М. Ивић, „Актуелност Белићевог погледа на именице”, у: Зборник радова о Александру Белићу (ур. М. Стевановић), Београд: САНУ, пос. издања, књ. CDXCVIII, 159-173.

Ивић 1998: М. Ивић, „Предговор приређивача овог издања”, Опита тингвистика, том 1, Изабрана дела Александра Белића, Београд: Завод за уџбенике и наставна средства, 5-12.

Ивић 22005: М. Ивић, Значеюа српскохрватског инструментала и юихов развој (Синтаксичко-семантичке студије), Београд: Српска академија наука и уметности - Београдска књига - Институт за српски језик САНУ.

Катичић 1976: R. Katičić, „Zabilješke uz sintagmatiku Aleksandra Belića”, y: Зборник радова о Александру Белићу (ур. М. Стевановић), Београд: CAHУ, 173-181.

Мухин 1987: А. М. Мухин, Системные отношения переходных глагольных лексем (на материале английского и русского языков), Ленинград: Наука.

Мразовић/Вукадиновић 1990: П. Мразовић, З. Вукадиновић, Граматика српскохрватског језика за страние, Сремски Карловци - Нови Сад: Издавачка књижарница Зорана Стојановића - Добра вест.

Пипер и др. 2005: П. Пипер, И. Антонић, В. Ружић, С. Танасић, Љ. Поповић, Б. Тошовић: Синтакса савременога српског језика. Проста реченииа, Београд - Нови Сад: Институт за српски језик САНУ - Београдска књига - Матица српска.

Петровић/Дудић 1989: В. Петровић, К. Дудић, Речник глагола, са граматичким и тексичким допунама, Београд - Нови Сад - Сарајево: Завод за уџбенике и наставна средства - Завод за издавање уџбеника - Свјетлост.

Петровић [Ружић] 1992: В. Петровић, „Прилог класификацији допунских адвербалних конструкција", Зборник Матище српске за филологију и тингвистику XXXV/2, 115-132.

Петровић [Ружић] 2000: В. Петровић, „О предлошком објекту у српском језику”, Зборник Матице српске за филологију и тингвистику XLIII: 437-445.

Прањковић 22002: I. Pranjković, Hrvatska skladnja. Rasprave iz sintakse hrvatskoga standardnog jezika. Zagreb: Hrvatska sveučilišna naklada. 
Ружић 2006: В. Ружић, „Исказивање типичног објекта номиналном допуном у српском језику", у: Зборник радова, САНУ [Одбор за савремени српски језик у светлу савремених лингвистичких теорија, Когнитивнолингвистичка проучавана српског језика], Београд, 283-301.

Силић/Прањковић 2005: J. Silić, I. Pranjković, Gramatika hrvatskoga jezika za gimnazije i visoka učilišta. Zagreb: Školska knjiga.

Симић 1999: Р. Симић, Основи синтаксе српскога језика, Београд - Никшић: Јасен.

Станојчић/Поповић 1992: Ж. Станојчић, Љ. Поповић, Граматика срискога језика. Београд: Завод за уџбенике и наставна средства - Нови Сад: Завод за издавање уџбеника.

Стевановић 1974: М. Стевановић, Савремени српскохрватски језик (Граматички системи и кюижевнојезичка норма) II. Синтакса, Београд: Научна књига.

Стевановић 1988: М. Стевановић, Од Вука до Белића и далье, Београд: Завод за уџбенике и наставна средства.

Vladislava Ružić

THE TIMELINESS OF BELIĆ'S VIEWS OF VERB COMPLEMENTS

Summary

The author surveys the contribution of Belićs doctrine of the subordinate phrase, especially of the verb-complement phrase, i.e. the scope of his syntagmatics in later European syntax. She has also demonstrated that his interpretation of complements was to a degree modified and absorbed into the studies of Serbian linguists. 